\title{
Australian Journal of \\ Crop Science \\ Yield of common bean cultivars and castor hybrids intercropped in two cultivation sites with oxisol in the Midwest region of Brazil
}

\author{
Rosane Angélica Anjos ${ }^{1}$, Cristiane Lisboa ${ }^{1}$, Gisele Silva ${ }^{1}$, Valter Vaz $^{1}$, Itamar Teixeira ${ }^{1 *}$, Marcos Eduardo \\ Araújo $^{2}$, Paulo César Corrêa ${ }^{2}$, José Hortêncio Mota ${ }^{3}$, Alessandro Silva ${ }^{4}$, Amanda Lourenço ${ }^{1}$
}

\author{
${ }^{1}$ State University of Goiás, BR 153, 75132-903, Anápolis - GO, Brazil \\ ${ }^{2}$ Federal University of Viçosa, Peter Henry Rolfs, 36570-900, Viçosa - MG, Brazil \\ ${ }^{3}$ Federal University of Goiás, 74690-900, Goiânia - GO, Brazil \\ ${ }^{4}$ University of Rio Verde, Fazenda Fontes do Saber, 75901-970, Rio Verde - GO, Brazil
}

*Corresponding author: itamar.texeira@ueg.br

\section{Abstract}

The consortium between bean and castor aims to increase the yield per unit area and sustainability in land use. This system has several benefits, but the use of different genetic materials must be carefully evaluated, especially the behavior of smaller castor hybrids, since little research on their use in a consortium system is available. This study aimed to evaluate the components of production and yield of common bean cultivars and small castor hybrids, in two field experiments conducted in the intercropping and monoculture systems, in 2015/2016 and 2016/2017 harvests, in two cultivation sites in the Midwest region of Brazil. The experiment was arranged in a completely randomized block design, in a $4 \times 2+6$ factorial scheme, composed of four common bean genetic materials of different growth types and colors (Pérola, BRS Esteio, BRS Pitanga, and BRSMG Realce), a consortium with two short castor hybrid cultivars (Tamar and Agima 110204) and six additional treatments and bean and castor genetic material in monoculture, with three replications. Agronomic components and grain yields were determined in both experiments, for bean cultivars and castor hybrids. Bean and castor genetic materials presented the same agronomic performance in the studied agricultural and local crops, regardless of the cropping system. The intercropping between common bean cultivars (BRS Esteio, BRSMG Realce and BRS Pitanga) and castor hybrids (Tamar and Ag Ima) was classified as viable by the area equivalence index, since this index presented values greater than 1.0 for the intercropping between these cultivars. Thus, it is recommended for common bean in a system intercropped with small castor hybrids, regardless of the cultivated genetic material.

Keywords: Association of crops; Grain yield; Phaseolus vulgaris L.; Planting locations; Ricinus communis L. Abbreviations: $A E I$ area equivalence indice; DAE_days after emergence.

\section{Introduction}

A growing number of research works have focused on the improvement of the techniques related to production systems, seeking to maximize the exploitation of natural resources and inputs used and minimize environmental impacts (Cunha et al., 2014; Santos et al., 2017).

Intercropping or consortium is the simultaneous exploitation of two or more species in the same area (Vieira et al., 2014), which has many advantages, such as the diversification of food production in a single area, optimization of labor, financial return in a shorter period of time, improved use of available resources and greater vegetative protection of the soil against erosion. Consequently, this system reduces pests, diseases and weeds, thus favoring the improvement of soil fertility as well as the development of plants, among other benefits, compared to perennial monocultures (Tchuenteu et al., 2013; Matos et al., 2014).

The consortium between castor (Ricinus communis L.) and common bean (Phaseolus vulgaris L.) is a promising alternative, since one of these species is considered a raw material for the production of numerous products of the ricino-chemical industry, while the other is considered a protein food source for the lower purchasing power classes of the Brazilian population, respectively (Teixeira et al., 2011).

Castor belongs to the Euphorbiaceae family and originates from the African continent. The main producing countries are India, China, Brazil and Mozambique, which account for $96 \%$ of production (Severino and Auld, 2014). Brazil is considered the third-largest producer, and the Northeast is the largest Brazilian producing region (Carvalho Júnior, 2016). The country has favorable conditions for the production of castors, but lacks technology, which led to the development of studies on the cropping system of this culture (Pivetta et al., 2017). Most of the reported scientific results on castor cultivation in the Midwest region address medium height to tall genetic material, with uneven maturity and manual harvesting (Cardoso et al., 2013; Cunha et al., 2014; Santos et al., 2017). However, a recent work conducted by Lisboa et al. (2018) using small castor hybrids adapted to mechanized harvesting detected their potential for cultivation under the common bean intercropping 
system, as well as in monoculture, in the "cerrado" conditions in Brazil.

Brazil is the world's largest producer and consumer of common beans. The crop belongs to the Fabaceae family, with 3.4 million hectares planted in the 2016/2017 crop, whose production reached 3.4 million tons of grain, with an average yield of $1,069 \mathrm{~kg} \mathrm{ha}^{-1}$ (Conab, 2018).

As previously mentioned, the production of castors and beans, especially by consortium, can improve the physical and chemical characteristics of the soil. It is also economically relevant due to their applications in industry and human consumption.

Castor oil is used in the industry to manufacture biofuels, soaps, lubricants, hydraulic and brake fluids, paints, dyes, coatings, cold-resistant plastic paints, polishing waxes, nylon, pharmaceutical products, perfumes and fertilizers (Mutlu et al. 2010; Lima et al., 2011; Kamalakar et al., 2015; Patel et al., 2016). Beans are mainly used for human consumption, since it is a cheap source of proteins, iron, calcium, zinc, B vitamins, carbohydrates, fibers and lysine (Vieira, 2006; Mesquita et al., 2007; Angioi et al., 2010; Embrapa, 2012).

The financial advantages of the consortium between castor and common bean were evidenced by Lisboa et al. (2018), who investigated the agronomic characteristics of common bean cultivars and castor hybrids, intercropped and in monoculture, and observed financial advantages in the intercropping between these crops, since, despite the average bean yield reduction of $463.66 \mathrm{~kg} \mathrm{ha}^{-1}$, the productivity of the hybrids was increased by $536.32 \mathrm{~kg} \mathrm{ha}^{-1}$. Given the importance of castor and bean crops and their social and financial relevance, the present work aimed to evaluate the yield and production components of common bean cultivars and small castor hybrids, in two crops, under the intercropping and monoculture systems, in two cultivation sites with oxisol, in the Midwest region of Brazil.

\section{Results and Discussion}

\section{Bean ratings}

The agronomic traits of bean under intercropping and monoculture were not affected by the crop factor, certainly due to the proximity of the two places $( \pm 200 \mathrm{~km})$ where the experiments were conducted, according to the geographic coordinates, since these experiments were conducted at the same cultivation period.

On the other hand, the agronomic traits of common bean under intercropping and monoculture systems were significantly affected by the isolated factor bean cultivars. Plant height, number of pods per plant and bean grain yield were significantly affected by castor hybrids, isolatedly, under the intercropping system. Regarding the interactions, it was verified that the bean $\mathrm{x}$ castor hybrid interaction affected plant height and number of pods per plant, while the interaction between intercropping and monoculture systems affected plant height, number of pods per plant and grain yield.

As for plant height, common bean presented higher values in consortium with the hybrid Tamar, except for cV. BRSMG Realce. Overall, regardless of the castor genetic material used in the intercropping system, the lowest values for bean plant height were verified in cvs. Pérola and BRSMG Realce, with averages of 58.4 and $43.8 \mathrm{~cm}$, respectively (Table 2). In relation to monocultures, cv. BRS Esteio was, once more, superior to the other cultivars in plant height, without statistical difference from cVs. BRSMG Realce and Pérola (Fig. 2A).

Considering the general averages, the higher number of pods per plant was observed for cV. BRS Esteio, followed by cv. Pérola (Table 3). However, the bean cultivars studied did not differ statistically for this trait under intercropping or monoculture systems (Fig. 2B). Teixeira et al. (2011) investigated the agronomic performance of cvs. Pérola, Graphite, Pontal, Requinte, Radiante and Diamante Negro, intercropped with tall castor cv. Paraguaçu, and verified that the number of pods per plant was the production component most affected by the intercropping system, which agrees with the present study.

Under intercropping, common bean plants did not differ in the number of grains per pod. However, numerically, cv. BRS Esteio was once again superior to the other cultivars and presented a higher number of grains per pod (Fig. 3A). BRSMG Realce stood out for presenting the highest 100grain mass, followed by cv. Pérola. Similarly to that observed in the consortium, CV. BRSMG Realce was superior in monoculture (Fig. 3B). For Cunha et al. (2014), 100-grain mass and number of grains per pod are production components little affected by environmental conditions that present high genetic heritability.

The grains of cvs. Pérola and BRS Esteio belong to the Carioca and Black commercial group and Mesoamerican breed. According to the Blair et al. (2010) classification, their grains are small, and the 100 -grain mass is less than $25.0 \mathrm{~g}$. Regarding grain yield, bean cultivars differed statistically from each other under intercropping. CV. Pérola presented higher productivity, followed by cvs. BRS Esteio and BRSMG Realce (Fig. 3C). On the other hand, the lowest yield was obtained by cV. BRS Pitanga. Bean plants reached higher levels of yield under monoculture, compared to intercropping, and there was statistical difference between them.

Results of research involving the intercropping of beans with large castors, such as cvs. BRS Paraguaçu, BRS Nordestina, Guarani and BRS Energia (Teixeira et al., 2011; Pereira et al., 2015), indicated that the technique reduced bean yield by up to $50 \%$, under the present condition.

\section{Castor ratings}

Regarding the joint analysis of variance for the agronomic traits of castor hybrids intercropped with common bean cultivars and their respective monocultures and the interaction between the two agricultural systems, evaluated in 2015/2016 and 2016 / 2017 harvests, it was observed that, regardless of the cultivation systems used, in two cultivation sites, no significant difference was detected between the agricultural harvests.

The agronomic traits of castor hybrids plant height and stem diameter were separately affected under the intercropped system by common bean cultivars, while stem diameter, 100 -grain mass, and grain yield were isolatedly affected by the castor hybrid factor. The significance of the interactions in intercropping was observed only in the $\mathrm{F} \times \mathrm{M}$ double interaction on plant height. In monoculture, the agronomic traits stem diameter, number of racemes per plant and 100grain mass were significantly affected by the isolated castor hybrid factor.

Although no significant difference was detected, regardless of the crop, numerically, the hybrid Agima presented plants with higher average height in intercropping and monoculture, while the plants belonging to the hybrid 
Table 1. Results of chemical analysis of samples (0-20 cm deep) of material from the soils used, in two cultivation sites in the State of Goiás, Brazil.

\begin{tabular}{lcc}
\hline & \multicolumn{2}{c}{ Cultivation of municipalities } \\
\hline Attributes & Anápolis & Ipameri \\
\hline $\mathrm{pH}\left(\mathrm{CaCl}_{2}\right)$ & 5.1 & 5.7 \\
$\mathrm{P}\left(\mathrm{mg} \mathrm{dm}^{-3}\right)$ & 3.0 & 3.7 \\
$\mathrm{~K}\left(\mathrm{cmol}_{\mathrm{c}} / \mathrm{dm}^{-3}\right)$ & 0.30 & 0.26 \\
$\mathrm{Ca}\left(\mathrm{cmol}_{\mathrm{c}} \mathrm{dm}^{-3}\right)$ & 3.2 & 1.9 \\
$\mathrm{Mg}\left(\mathrm{cmol}_{\mathrm{C}} \mathrm{dm}^{-3}\right)$ & 1.0 & 0.9 \\
$\mathrm{Al}\left(\mathrm{cmol}_{\mathrm{Cm}} \mathrm{dm}^{-3}\right)$ & 0.0 & 0.0 \\
$\mathrm{H}+\mathrm{Al}\left(\mathrm{cmol}_{\mathrm{c}} \mathrm{dm}^{-3}\right)$ & 3.1 & 2.1 \\
$\mathrm{~V}(\%)$ & 60.0 & 59.0 \\
$\mathrm{Zn}\left(\mathrm{mg} \mathrm{dm}^{-3}\right)$ & 1.7 & 4.7 \\
Organic matter $\left(\mathrm{g} \mathrm{dm}^{-3}\right)$ & 23.0 & 20.0 \\
Sand $\left(\mathrm{g} \mathrm{kg}^{-1}\right)$ & 500.0 & 620.0 \\
Silt $\left(\mathrm{g} \mathrm{kg}^{-1}\right)$ & 50.0 & 80.0 \\
Clay $\left(\mathrm{g} \mathrm{kg}^{-1}\right)$ & 450.0 & 300.0 \\
\hline
\end{tabular}
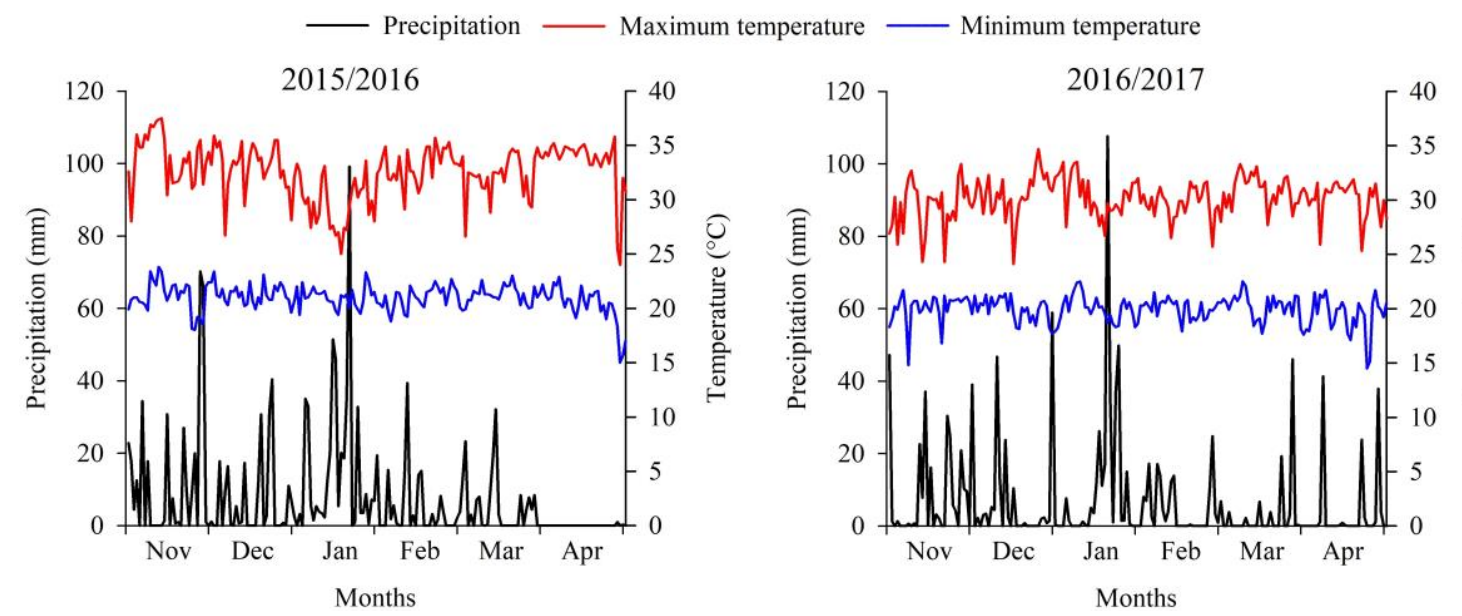

Fig 1. Daily climate data for precipitation $(\mathrm{mm})$, maximum temperature $\left({ }^{\circ} \mathrm{C}\right)$ and minimum temperature $\left({ }^{\circ} \mathrm{C}\right)$ for the period of conductance of the 2015/16 (Anápolis, GO) and 2016/17 (Ipameri, GO) harvests. (Data provided by the Instituto Nacional de Meteorologia - INMET-GO).

Table 2. Average values of plant height $(\mathrm{cm})$ of common bean cultivars intercropped with castor hybrids for the common bean cultivar x castor hybrid interaction in the 2015/16 (Anápolis, GO) and 2016/17 (Ipameri, GO) agricultural harvests.

\begin{tabular}{lllll}
\hline Castor hybrids & \multicolumn{3}{c}{ Common bean cultivars } & \\
\cline { 2 - 5 } & Pérola & Esteio & Realce & Pitanga \\
Tamar & $59.2 \mathrm{Ac}$ & $86.7 \mathrm{Aa}$ & $41.9 \mathrm{Ad}$ & $68.0 \mathrm{Ab}$ \\
Agima & $57.6 \mathrm{Ab}$ & $70.8 \mathrm{Ab}$ & $45.8 \mathrm{Ac}$ & $57.6 \mathrm{Bb}$ \\
Overall average & 58.4 & 78.7 & 43.8 & 62.8 \\
\hline
\end{tabular}

Averages followed by the same letter, uppercase letter in the column and lowercase in the row, do not differ from each other at 5\% probability by the Scott-Knott test.
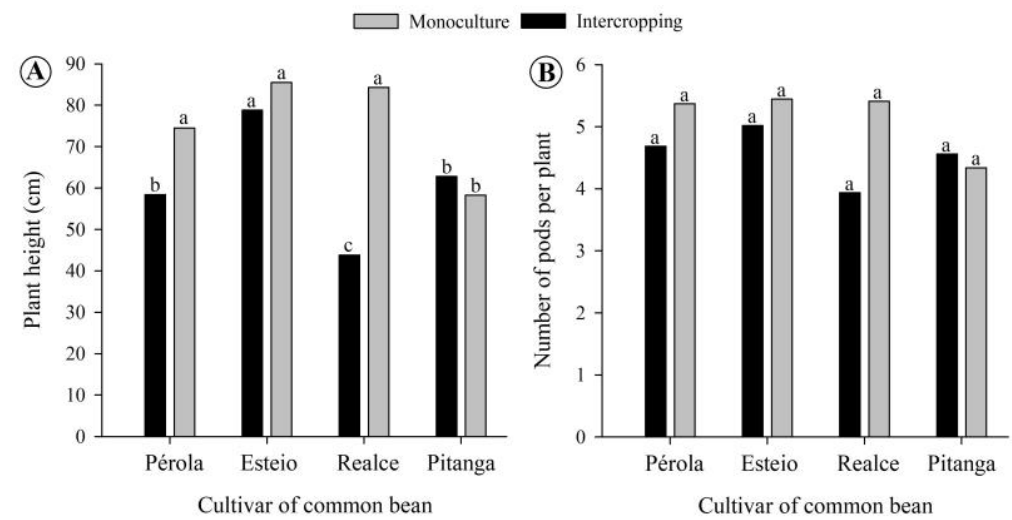

Fig 2. Plant height $(A)$ and number of pods per plant $(B)$ of common bean cultivars intercropped with castor hybrids and monocultures in the 2015/16 (Anápolis, GO) and 2016/17 crops (Ipameri, GO). 
Table 3. Average values of number of pods per plant of common bean cultivars intercropped with castor hybrids for the common bean cultivar x castor hybrid interaction in the 2015/16 (Anápolis, GO) and 2016/17 (Ipameri, GO) agricultural harvests.

\begin{tabular}{lllll}
\hline Castor hybrids & \multicolumn{3}{c}{ Common bean cultivars } & \\
\cline { 2 - 5 } & Pérola & Esteio & Realce & Pitanga \\
Tamar & $12.7 \mathrm{Ab}$ & $16.3 \mathrm{Aa}$ & $9.8 \mathrm{Ac}$ & $12.5 \mathrm{Ab}$ \\
Agima & $12.8 \mathrm{Aa}$ & $13.2 \mathrm{Ba}$ & $10.4 \mathrm{Ab}$ & $8.9 \mathrm{Bb}$ \\
Overall average & 58.4 & 78.7 & 43.8 & 62.8 \\
\hline
\end{tabular}

Means followed by the same letter, uppercase letters in the column and lowercase in the row do not differ from each other at $5 \%$ probability by the Scott-Knott test.
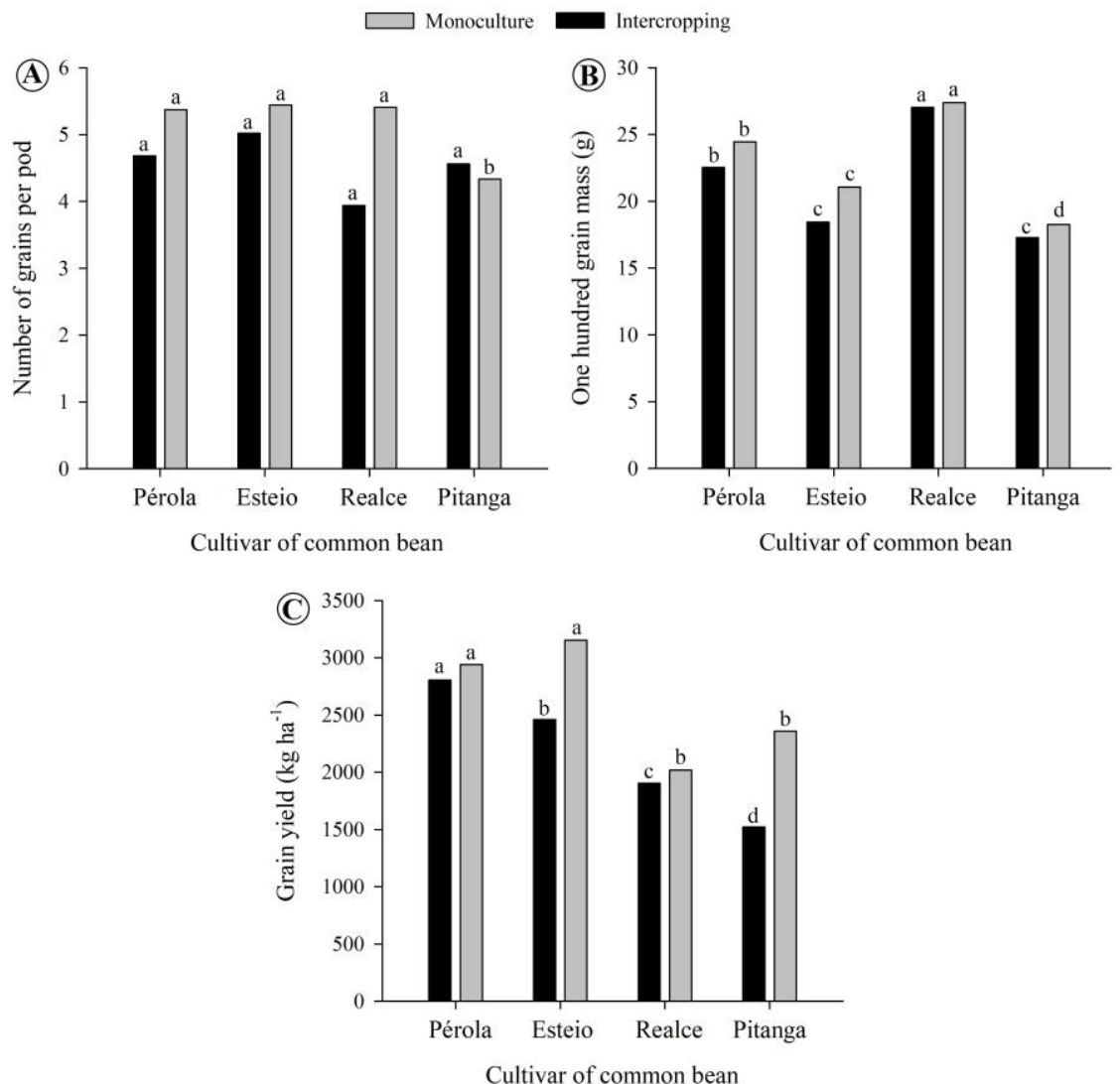

Fig 3. Number of grains per pod (A), one hundred grain mass $(B)$ and grain yield $(C)$ of common bean cultivars intercropped with castor hybrids and under monoculture in the 2015/16 (Anápolis, GO) and 2016/17 agricultural harvests (Ipameri, GO).

Table 4. Average values of plant height $(\mathrm{cm})$ of castor hybrids intercropped with common bean cultivars for common bean $\mathrm{x}$ castor hybrid interaction in the 2015/16 (Anápolis, GO) and 2016/17 (Ipameri, GO) agricultural harvests.

\begin{tabular}{|c|c|c|c|c|}
\hline \multirow[t]{2}{*}{ Castor hybrids } & \multicolumn{4}{|c|}{ Common bean cultivars } \\
\hline & Pérola & Esteio & Realce & Pitanga \\
\hline Tamar & $93.3 \mathrm{Ab}$ & $80.0 A b$ & $93.3 \mathrm{Ab}$ & 123.3Aa \\
\hline Agima & 106.7Aa & 96.7Aa & 86.7Aa & $96.7 \mathrm{Ba}$ \\
\hline Overall averages & 100.0 & 88.4 & 90.0 & 110.0 \\
\hline
\end{tabular}

Averages followed by the same letters, uppercase letter in the column and lowercase in the row, do not differ from each other at 5\% probability by the Scott-Knott test

Table 5. Intercropping (c) and monoculture $(\mathrm{m})$ yield of common bean ( $\mathrm{Fc} / \mathrm{Fm}$ ) and castor hybrids (Mc / Mm) and AEl in 2015/16 (Anápolis, GO) and 2016/17 (Ipameri, GO) agricultural harvests.

\begin{tabular}{|c|c|c|c|c|c|c|}
\hline \multirow[t]{2}{*}{ Common bean cultivars } & \multicolumn{3}{|c|}{ Castor hybrid Agima } & \multicolumn{3}{|c|}{ Castor hybrid Tamar } \\
\hline & $\mathrm{Fc} / \mathrm{Fm}$ & $\mathrm{Mc} / \mathrm{Mm}$ & $\mathrm{AEI}$ & $\mathrm{Fc} / \mathrm{Fm}$ & $\mathrm{Mc} / \mathrm{Mm}$ & $\mathrm{AEI}$ \\
\hline Pérola & 1.05 & 1.02 & 2.07 & 0.85 & 0.95 & 1.80 \\
\hline Esteio & 0.78 & 1.05 & 1.83 & 0.77 & 0.90 & 1.67 \\
\hline Realce & 0.41 & 0.98 & 1.39 & 0.88 & 0.74 & 1.62 \\
\hline Pitanga & 0.70 & 0.88 & 1.58 & 0.58 & 1.31 & 1.89 \\
\hline Average & 0.73 & 0.98 & 1.72 & 0.77 & 0.97 & 1.74 \\
\hline
\end{tabular}



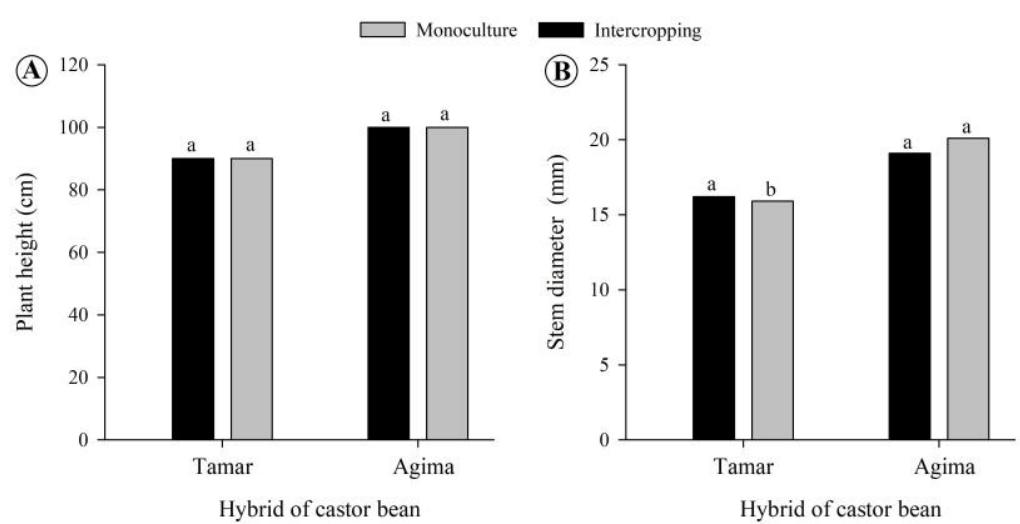

Fig 4. Plant height (A) and stem diameter (B) of castor hybrids intercropped with common bean cultivars and under monoculture in the 2015/16 (Anápolis, GO) and 2016/17 crops (Ipameri, GO).
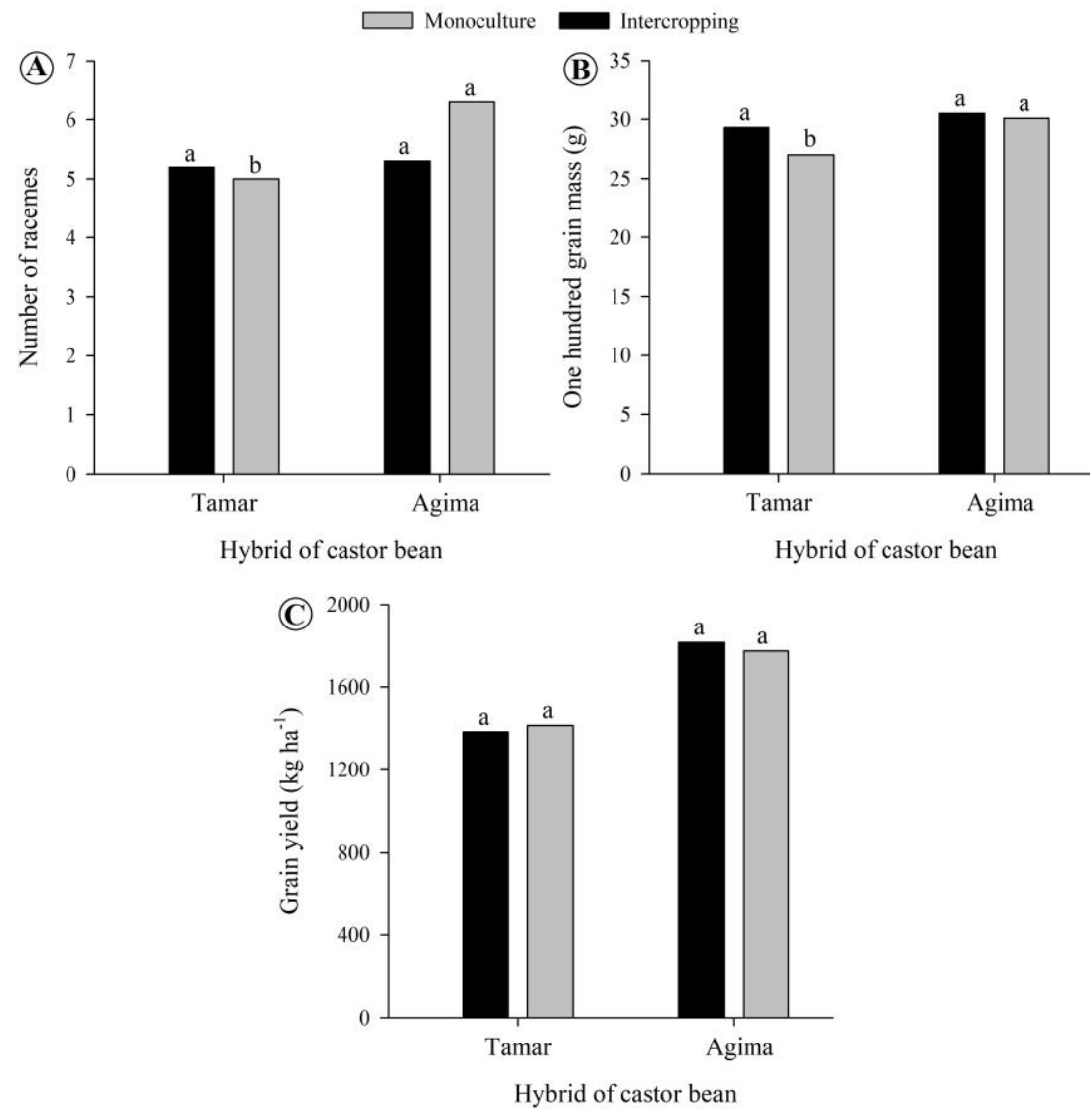

Fig 5. Number of racemes (A), one hundred grain mass (B) and grain yield (C) of castor hybrids intercropped with common bean cultivars and under monoculture in the 2015/16 (Anápolis, GO) and 2016/17 agricultural harvests (Ipameri, GO).

Tamar presented lower average height in both cultivation systems (Table 4 and Fig. 4A).

Considering the competition for light in intercropping systems, in plantations with low availability of solar radiation due to population density, castor plants tend to grow excessively (Severino et al., 2006). Regarding stem diameter, the averages differed only in monoculture, mainly for the hybrid Agima, which presented larger stem diameter (Fig. 4B).

The castor hybrids presented no difference for the number of racemes per plant produced under intercropping, with identical values of racemes per plant (Fig. 5A). However, when conducted in monoculture, the hybrid Agima presented significantly higher results of racemes per plant than the Tamar hybrid.
The 100-grain mass rate was close and non-significant among the castor plants under consortium (Fig. 5B). In monoculture, the 100-grain mass-produced differed significantly among hybrids, and the highest mass value was obtained for Agima.

Regarding grain yield, no significant difference for castor hybrids was observed between the intercropping and monoculture systems (Fig. 5C). The results obtained between the cropping systems demonstrate that the intercropping with beans did not affect the grain yield of castor hybrids studied and cultivated under intercropping and monoculture.

Although the intercropping system affected only the grain yield of the bean genetic materials investigated, the results obtained with $\mathrm{AEI}$, which involved the association of common bean cultivars with small castor hybrids, 
demonstrated that all intercropping systems were viable in relation to the isolated cultivation of the two crops (monoculture) (Table 5).

The results for the obtained AEI corroborate the findings of Teixeira et al. (2011), who investigated the agronomic performance of six bean cultivars intercropped with largecastor (Paraguaçu). All AEI calculated results corroborated the efficiency of the intercropping system, with values ranging from 1.38 to 1.71 .

\section{Materials and Method}

\section{Plant materials}

The experiments were carried out in the 2015/2016 and 2016/2017 harvests, in the municipalities of Anápolis and Ipameri, respectively, both located in the State of Goiás, Brazil, in the experimental areas of Emater and Universidade Estadual de Goiás, Ipameri Campus, with the following geographical coordinates: 16019' $\mathrm{S}$ and $48.18^{\prime} \mathrm{W}$, at an average altitude of $1050 \mathrm{~m}$; 17녀' $\mathrm{S}$ and 48.09' W, with average elevation of $820 \mathrm{~m}$. Climate data of rain and monthly average temperature during the period of the experiments are presented below (Fig. 1).

Soil samples, classified as Dystroferric Red Yellow Latosol (Embrapa, 2013), were collected from two cultivation sites at the depth of $0-20 \mathrm{~cm}$ and sent to the laboratory for physical-chemical analysis, which presented the following results in Anápolis and Ipameri, respectively (Table 1).

\section{Experimental design and treatments}

The experiment was arranged in a randomized block design, in a $4 \times 2+6$ factorial scheme, composed of four common bean genetic materials of different growth types and colors (Pérola, BRS Esteio, BRS Pitanga, and BRSMG Realce), in consortium with two short castor hybrid cultivars (Tamar and Agima 110204) and six additional treatments, bean and castor genetic material in monoculture), with three replications.

The bean cultivars investigated are characterized as Pérola (Carioca), ordinary cycle (85-95 days) and undetermined growth habit (type II / III); BRS Esteio (Black), ordinary cycle (89-95 days) and undetermined growth habit (type II); BRSMG Realce (Brindle), semi-early cycle (75-84 days) and determined growth habit (type I); BRS Pitanga (Purple), normal cycle (85-95 days) and undetermined growth habit (type II). On the other hand, the castor hybrids are the following: Tamar (140-160 days), with an average height of $160-170 \mathrm{~cm}$ and sympodial stem growth; Agima110204 (140-160 days), with an average height of $170-180 \mathrm{~cm}$ and sympodial stem growth.

\section{Conduction of study}

The castor plots under the intercropping system consisted of four $5.0 \mathrm{~m}$ long rows, with a spacing of $1.0 \mathrm{~m}$ between them. Two rows of beans were placed between the lines of castor, with a spacing of $0.5 \mathrm{~m}$. The two central lines of castor and common bean were taken as a useful plot area. In the monoculture system, the castor and bean plots had four 5.0 $\mathrm{m}$ long rows and spacing of $1.0 \mathrm{~m}$ for castor and $0.5 \mathrm{~m}$ for bean, and the two central lines were harvested as useful area.

Basic fertilization was performed by applying the formulation 08-28-18 at a dose of $400 \mathrm{~kg} \mathrm{ha}^{-1}$ in both areas, for each crop individually. Then, the castor seed and common bean seeds were simultaneously sown by hand, in the two cultivation sites, on November 15, 2015, and November 17, 2016, and $25 \%$ more seeds were used in the sowing of the two crops. Thinning was performed 10 and 15 DAE, aiming to reach castor and bean densities of 2 and 12 plants per linear meter, respectively. At $30 \mathrm{DAE}, 40 \mathrm{~kg} \mathrm{ha}^{-1}$ nitrogen topdressing was performed in a continuous fillet along each bean and castor plantation line, and urea as the source for both crops in both areas.

\section{Traits measured}

In the useful area of each experimental unit, in the two bean cultivation areas, 10 plants were randomly collected for plant height evaluation (measurement from soil to plant apex) and determination of grain yield components, which were: number of pods per plant, number of grains per pod and average 100 -grain mass. The trail to determine the grain yield was used for the remaining plants harvested.

The castor plants were harvested in the useful area of the cultivation plots, and four of them were used to determine the following traits: plant height, stem diameter $(0.01 \mathrm{~mm}$ digital caliper, about $2 \mathrm{~cm}$ from the soil), number of racemes per plant and average 100-grain mass. Grain yield was obtained by trailing all plants harvested in the useful area of the experimental plots. The results were expressed for the moisture content of $12 \%$ (wet basis).

For each system evaluated, the AEI, described by Vieira et al. (2006), was also determined. This index quantifies the number of hectares needed for the production in monocropping to become equal to that of one hectare of the same crops cultivated in association (Eq. 1).

$\mathrm{AEI}=\frac{F_{i}}{F_{m}}+\frac{M_{i}}{M_{m}}$

where:

$F_{i}$ - yield of intercropped common bean;

$F_{m}$ - yield of common bean in monocropping;

$\mathrm{M}_{\mathrm{i}}$ - yield of intercropped castor; and,

$\mathrm{M}_{\mathrm{m}}$ - yield of common bean in monocropping.

Intercropping is efficient when AEI is higher than 1.0, because more than 1 hectare of monocropping will be required to produce the same as 1 hectare of intercropping.

\section{Statistical analysis}

The data of the agronomic components of common bean and castor hybrids were initially submitted to individual variance analysis, in the two agricultural years, under intercropping and monoculture systems. Then, it was performed the analysis of the joint variance of the traits present in both experiments, based on Banzatto and Kronka (2006). Where relevant, a 5\% probability Scott-Knott test was employed to discriminate the effects of the crop sites, genetic materials of common bean and castor hybrids, and cropping systems. The effects of the interactions between intercropping $\mathrm{x}$ monoculture systems were studied by the Dunnet's test at $5 \%$ probability. The data were analyzed by the Sisvar 5.6 statistical analysis software system (Ferreira, 2011).

\section{Conclusions}

Bean cultivars and castor hybrids presented a similar agronomic performance in the agricultural and local crops studied, regardless of the cropping system.

Pérola is the bean cultivar most suitable for intercropping with castor hybrids Agima and/or Tamar. 
The intercropping of common bean with small castor hybrids is viable under monoculture and rated by $A E I$ as higher than 1.0, regardless of the genetic materials used and the agricultural crop year.

Declarations of interest: The authors declare that they have no known competing financial interests or personal relationships that could have seemed to influence the work reported in this paper.

\section{References}

Angioi SA, Rau D, Attene G, Nanni L, Bellucci E, Logozzo G. Negri V, Spagnoletti zeuli P.L, Papa R (2010) Beans in Europe: origin and structure of the European landraces of Phaseolus vulgaris L. Theor Appl Genet. 121: 829-843.

Banzatto DA, Kronka SN (2006) Experimentação agrícola. 4.ed. Jaboticabal, SP: Funep.

Blair MW, González LF, Kimani PM, Butare L (2010) Genetic diversity, inter-gene pool introgression and nutritional quality of common beans (Phaseolus vulgaris L.) from Central Africa. Theor Appl Genet. 121(2): 237-248.

Cardoso FR, Galante AHA, Teixeira IR, Silva AG, Reis EF (2013) Fontes e doses de zinco na nutrição e produção de feijão-comum e mamona em consórcio. Rev Bras Ciênc Agrár. 8(4): 602-609.

Carvalho Júnior GS, Lima RLS, Gheyi HR, Carvalho JMFC, Soares MRA, Sofiatti V (2016) Physiological aspects of castor CV. BRS Energia in response to foliar application of gibberellic and salicylic acid. Aust J Crop Sci. 10(2): 193198.

Conab - Companhia Nacional de Abastecimento (2018) Acompanhamento da safra brasileira de grãos - safra 2017/2018, boletim setembro de 2018. Brasília, DF. https://www.conab.gov.br/info-agro/safras. (accessed 21 October 2018).

Cunha DA, Teixeira IR, Jesus FF, Guimarães RT, Teixeira GCS (2014) Adubação fosfatada e produção de feijão-comum e mamona em consórcio. Biosc J. 30(2): 617-628.

Embrapa - Empresa Brasileira de Pesquisa Agropecuária. 2013. Sistema brasileiro de classificação de solos. 3.ed. Brasília, 353p.

Embrapa - Empresa Brasileira de Pesquisa Agropecuária (2013) Morfologia- feijão. Available in: <http://www.agencia.cnptia.embrapa.br/Agencia4/AG01/ arvore/AG01_9_1311200215101.ht ml>. accessed on April 1, 2013.

Ferreira DF (2011) Sisvar: um sistema computacional de análises estatística. Cienc Agrotec. 35(6): 1039-1042.

Kamalakar K, Mahesh G, Prasad RBN, Karuna MSL (2015) A novel methodology for the synthesis of acyloxy castor polyol esters: low pour point lubricant base stocks. J Oleo Sci. 64(12): 1283-1295.

Lima RLS, Severino LS, Sampaio LR, Sofiatti V, Gomes JA, Beltrão NEM (2011) Blends of castor meal and castor husks for optimized use as organic fertilizer. Ind Crops Prod. 33(2): 364-368.
Lisboa CF, Silva DDA, Teixeira IR, SILVA AG, Mota JH (2018) Agronomic characteristics of common bean and castor hybrids in intercropping and monocropping. Rev Bra Eng Agríc Ambient. 22(3): 200-205.

Matos FS, Carvalho DDC, Souza AC, Neves TG, Ribeiro RP, Cruvinel CKL, Rosa VR, Santos PGF (2014) Viabilidade agronômica do consórcio entre pinhão manso e soja. Agrarian. 7(24): 226-232.

Mesquita RF, Corrêa, DA, Abreu PMC, Lima, ZAR, Abreu, BFA (2007) Linhagens de feijão (Phaseolus vulgaris L.): Composição química e digestibilidade protéica. Cienc Agrotec. 31(4): 1114-1121.

Mutlu H, Meier MAR (2010) Castor oil as a renewable resource for the chemical industry. Eur J Lipid Sci Technol. 112(1): 10-30.

Patel VR, Dumancas GG, Viswanath LCK, Maples R, Subong BJJ (2016) Castor oil: Properties, uses, and optimization of processing parameters in commercial production. Lipid Insights. 9(7): 1-12.

Pereira FS, Teixeira IR, Pelá A, Reis EF, Silva GC, Timossi PC, Silva AG (2015) Agronomic performance of kidney bean and castor cultivars in intercropping and monocropping systems under weed competition. Aust J Crop Sci. 9(7): 614-620.

Pivetta LG, Tomaz CA, Fioreze SL, Fioreze ACCL, Pivetta LA, Zanotto MD (2017) Growth performance of castor hybrids under different plant densities. Ceres. 64(4): 399-412.

Santos FLS, Teixeira IR, Timossi PC, Silvério JCD, Benett CGS (2017) Phytosociological survey of weed plants in intercrops of common beans and castors. Planta Daninha. 35: $1-12$

Severino LS, Auld DL (2014) Study on the effect of air temperature on seed development and determination of the base temperature for seed growth in castor (Ricinus communis L.). Aust J Crop Sci. 8(2): 290-295.

Severino LS, Moraes CRA, Gondim TMS, Cardoso GD, Beltrão NEM (2006) Crescimento e produtividade da mamoneira influenciada por plantio em diferentes espaçamentos entre linhas. Rev Ciênc Agron. 37(1): 50-54.

Tchuenteu TL, Megueni C, Njintang YN (2013) A study of the variability for grain and oil yield and yield related traits of castors accessions in two savannah agro-ecological zones of Cameroon. Int J Biosci. 3(8):251-63.

Teixeira IR, Silva GC, Timossi PC, Silva AG (2011) Desempenho agronômico de cultivares de feijão-comum consorciado com mamona. Rev Caatinga. 24(4): 55-61.

Vieira C (2006) Cultivos consorciados. In. Vieira C, Paula Jr. TJ, Borém A (Eds.) Feijão. 2.ed. Viçosa, MG. 2.

Vieira JCB, Puiatti M, Cecon PR, Bhering AS, Silva GCC, Colombo N (2014) Viabilidade agroeconômica da consorciação do taro com feijão-vagem indeterminado em razão da época de plantio. Ceres. 61(2): 229-233. 